\title{
Theory-Generating Practice: Proposing a principle for learning design
}

Mie Buhl

Professor mso

Institut for Kommunikation, Aalborg Universitet (Kbh)

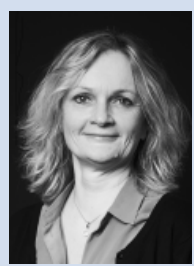




\section{Abstract}

Denne artikel introducerer Teori-Genererende Praksis (TGP) som et princip for læringsdesign i teknologiunderstøttede læreprocesser. Målet er at bidrage til den teoretiske videreudvikling af læringsdesign for universitetsundervisning, der bryder med mere traditionelle organiseringer i kurser med teoriformidling i en række lektioner efterfulgt af en afsluttende eksamen eller et projekt. TGP som design princip fokuserer på en organisering, der faciliterer 'gøren erfaring med' forud for tilegnelsen af teori med henblik på at aktivere tavs viden som en del af videnstilegnelsen. Argumentet er, at denne tilgang fremmer den lærendes videndannelsesproces. Introduktionen af designprincippet TGP tager afsæt i forfatterens praktiske og teoretiske afsæt i en dansk didaktiktradition, som diskuteres i forhold til nyere strømninger af didaktisk design og læringsdesign. Derefter udfoldes det teoretiske grundlag for TGP, som diskuteres og eksemplificeres med tre empiriske afprøvninger , der er gennemført og evalueret på tre forskellige fag på bachelor og kandidatuddannelsesniveau.

\section{Abstract}

This contribution proposes a principle for learning design - Theory-Generating Practice (TGP) - as an alternative to the way university courses are traditionally taught and structured, with a series of theoretical lectures isolated from practical experience and concluding with an exam or a project. The aim is to contribute to the development of theoretical frameworks for learning designs by suggesting TGP, which may lead to new practices and transpose the traditional dramaturgy for teaching TGP focuses on embodied experience prior to text reading and lectures to enhance theoretical knowledge building, and takes tacit knowledge into account. The article introduces TGP, contextualizes it to a Danish tradition of didactics, and discusses it in relation to contemporary conceptual currents of didactic design and learning design. This is followed by a theoretical framing of TGP. Finally, three empirical examples from bachelor and master programs involving technology are used to demonstrate three ways of practicing this alternative learning design.

\section{Introduction to theory-generating practice as a principle for learning design}

How do we develop teaching practices in higher education in light of digital technologies? What are the appropriate approaches to planning and practicing teaching? How can one subject domain inform and inspire others to develop new teaching and learning practices?

This article proposes a principle for planning and practicing teaching in higher education with the suggestion that students engage with theoretical issues from a practical approach to enhance theoretical knowledge. A practical 
approach to theoretical knowledge may contribute to develop not only the students' learning outcomes, but also our theoretical thinking about university pedagogy. I call this principle theory-generating practice (TGP).

I began to work with the idea in my own teaching practice in higher ducation and have developed it in different forms over the years. From this practice, and from empirical and theoretical research in the field of art education (Buhl, 2002), I developed the principle of TGP, which I will introduce and discuss. By "principle for learning design," I mean planning and practicing learning based on students' "Doing first, and then reflecting on the experience of doing it." The development of this design and the theoretical framework behind it emerge from an education paradigm formed by my theoretical background in educational research and pedagogy with a specialization in visual arts education that draws on both the continental tradition of Didaktik with reference to constructivism and current Anglo-Saxon developments in learning design. My Danish perspective between two currents provides dynamic theoretical inspiration to my suggestion of the particular principle for learning design. While the concept of didactics has a long tradition in a Danish context, the concept of learning design is new. Both concepts derive from the need to define a starting point for making decisions for organizing and practicing teaching.

My discussion is motivated by the fact that templates for courses - either offline, online, or blended - are traditionally structured in the same way: theoretical lectures, workshops, and exercises building up to a final project, where each student's ability to meet the learning objectives is assessed. Years of working with project-oriented approaches has taught me that this building up to a final performance makes it difficult for the student to actually connect to the theoretical course content and acknowledge the association between the build-up and the actual project. Often the relevance of theory is not revealed until the project work is at its highest level of activity - in the very last part of the course, when the project must be finalized. But what if the dramaturgy of a session, a module, a course, or a term could be organized in a more effective way? What if the learning curve could be stimulated to a high level from the very beginning?

TGP frames students' learning processes in a way that supports their experiences through actual "doing" and "living through" a learning activity in a practical way in technology-supported environments. These processes provide students with embodied knowledge emerging from the actual performance of a learning activity and constitute what I denote theorygenerating practice. This approach to learning enhances students' ability to identify and work with challenges that emerge during the learning process in a way that elicits issues that can be reflected upon theoretically; give rise to the generation of new knowledge; and efurther develop existing theory. I argue that this approach to learning enhances students' ability to set a 
problem and to conduct the phases of problem solving. Thus, TGP offers a fresh take on how students' learning processes can be enhanced and how their theoretical knowledge building can be supported. In the practice of TGP, the tasks of the educator are to frame and orchestrate the learning activities throughout a course to facilitate an experiential process of doing; to time and frame theoretical lectures to further students' reflexive process of problem setting and reframing; and to facilitate experiencing as an act of knowing.

One might ask what is to be gained from this approach. The article suggests that even though the concepts of learning and the learner have been the center of pedagogical discussions since the 1990s (e.g., Lave \& Wenger, 1991; Conole, 2013); despite the fact that the implementation of information and communication technology (ICT) has been addressed as critical for delivering adequate education since the beginning of the millennium (e.g., McAuley et al., 2010); and even though the combination of learning and technology has illustrated the necessity of reframing the very paradigm of education (e.g., Siemens, 2005; Daziel et al., 2013; Daziel, 2015), many discussions of elearning in higher education still take their point of departure in the traditional format of formal education that occurs in a lecture hall, with one lecturer teaching an audience of students.

Educational design scientists Mor et al. (2015) addressed this challenge by approaching the teacher-learner situation as a design matter. They defined learning design with the following quote from a previous publication by Mor and Craft (2012): "the creative and deliberate act of devising new practices, plans of activity, resources and tools aimed at achieving particular educational aims in a given context" (p. 86). Furthermore, they add that it "should be informed by subject knowledge, pedagogical theory, technological knowhow, and practical experience, and at the same time, it should also engender innovation in all these domains and support learners in their efforts and aims," (Mor et al., 2015, p. x). Their statement emphasizes the complexity of design used for the purpose of what they express learning to be - a "change of human condition" - which distinguishes their position from that of scholars who advocate for learning as organizational or systemic (e.g., Siemens, 2005). Either way, I find the commonality of "change" between the positions essential to how we can understand and connect learning with design. Learning design is about facilitating change. How we connect change to human intentionality indicates the degree to which learning is a matter of instrumental skills or the criteria for making use of the learning skills as well. However, emerging discussions of how digital media is changing learning paradigms are important actors in our ongoing endeavors to develop learning theory and theory of learning designs. TGP contributes to this discussion by suggesting hands-on practice prior to theoretical thinking.

TGP gives rise to a discussion of a more appropriate orchestration of university teaching to prepare students to work in a changeable future and 


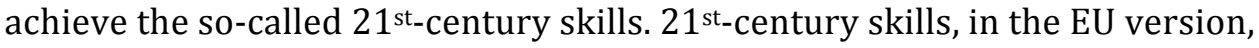
comprise themes like "critical thinking, creativity, initiative taking, problemsolving, risk assessment, decision taking and managing feelings constructively" (EU Commission, 2008, p. 5) along with the more "'traditional' competences such as communication in the mother tongue, communication in foreign languages, mathematical competence and basic competences in science and technology, and digital competence, but also the more transversal ones such as learning to learn, social and civic competences, sense of initiative and entrepreneurship, and cultural awareness and expression" (EU Commission, 2008, p. 5). I argue that TGP enhances the stated themes because practical experience from "doing" concretizes conceptual abstractions and gives rise to theoretical issues which cannot be calculated hypothetically.

My discussion of the principle of TGP is structured in three steps. First, I contextualize it to a Danish context, drawing on the concept of didactics and discussing TGP in relation to contemporary currents of didactic design and learning design. Next, I describe its domain-specific origin from Danish visual arts education, introduce the theoretical framework of tacit knowledge based on practical experience, and argue that TGP promotes the potential of this tacit knowledge in other domains. Finally, I present three examples from three different subject areas in university teaching where I have practiced and evaluated TGP: counseling; ICT-based learning design; and digital visual cultures and learning design.

\section{Conceptual approaches to learning design}

As stated by Mor et al. (2015), learning design is a many-faceted concept and develops along with conceptual developments of instructional design. The authors acknowledge the confusion among practitioners and researchers regarding the two concepts, which at the outset represent different pedagogical ideas. While learning design refers to constructivist theory and connects to technology-enhanced learning in the 1990s and 2000s, instructional design refers to behaviorist theory and goes back to the Second World War, where rapid training in technical skills for the production of war materials was needed. However, the concepts are developed and used in a manner where the two domains overlap, and the distinction between them seems difficult to maintain. The complexity of how to find a common conceptual outset for discussions of the matters are well-known in a Nordic context. On the one hand a conceptual outset drawing on the continental developments of didactics, or Didaktik, as the conceptual framing for discussions of constructivist as well as behaviorist theories of organizing; on the other hand contextualizing learning content and learning processes from the Anglo-Saxon tradition, which addresses teaching and learning according to the curriculum rather than implying the conditions under which curriculum activities take place (Hopmann \& Gundem, 1998). 
In a Danish context, discussions of the concept of didactics have developed among scholars informed by many fields: pedagogy and philosophy, emphasizing the general educational and socialization aspect articulated in the German concept Bildung (e.g., Klafki, 2001); sociology (e.g., Habermas, 1996), emphasizing societal conditioning, either for a critical framing of educational goals and content or for a systemic description of mechanisms in the logic of educational development (e.g., Luhmann, 2000, 2002); psychology, emphasizing knowledge construction as an individual as well as a social activity (e.g., Vygotsky, 1991); and anthropology, emphasizing the social practices of human behavior as the driver of learning and culture (e.g., Lave \& Wenger, 1991). These discussions of didactics are also rooted in the former Royal Danish School of Educational Studies' traditional theoretical framework for pedagogical modeling of teaching and learning (e.g., Larsen/Høegh-Larsen, 1997) as well as theoretical frameworks connected to school subjects and teacher education (e.g., Nielsen, 1998; Schnack, 2004, Buhl, 2002). Studies from American scholars (e.g., Dewey 1979, Schön, 1983) inform pragmatic approaches to highlight the importance of integrating a Nordic experiencing as a core activity in discussions of the interrelationship between teacher, content, and students (Hopmann \& Gundem, 1998), an activity Dale (1989) advocates for professionalization, emphasizing the level of theoretical reflection as crucial for the professional teacher. The levels of planning and practicing are not enough; they must be reflected based on theoretical knowledge.

Along with the emergence of ICT, discussions of the relationship between technology and didactics develop among scholars working with technology that draws on the theoretical frameworks that emerge from this Nordic tradition. Technology's being more than an added tool is discussed as ITdidactic design (e.g., Andreasen, Meyer, \& Ratleff, 2008; Holm Sørensen, Audon, \& Levinsen, 2010; Meyer, 2011), emphasizing the constructivistpragmatic approach in a technological landscape, which expands and changes the perception of time and space, as well as access to information and knowledge construction, the framing of social practices, and the conditions for societal thought patterns. In rethinking didactics, the concept of design is the acknowledgment of a paradigmatic change where the classical Herbatian relationship between teacher, content, and learner (Jank \& Meyer, 1991) not only expands by further factors influencing the learning process (e.g., Hiim \& Hippe, 1997); it develops toward a change which involves stakeholders outside the well-known "teaching - content - learning space," pointing at an approach where didactics can be comprehended and differentiated in phases of didactics as separate entities rather than a unity, as suggested by Dobozy (2011) in her conceptual reframing of learning design. Daziel et al. addressed these issues in The Larnaca Declaration on Learning Design-2013 by suggesting a model for components of the field of learning design, dividing the concept into the following: the Learning Design Conceptual Map (LD-CM), 
Learning Design Framework (LD-F), and Learning Design Practice (LD-P). They take their point of departure by outlining a situation where the actors are multiple and have many facets and the activities are not necessarily orchestrated by a trained teacher or institutionalized in a traditional university structure. Furthermore, the involvement of technological devices and features in the activities adds another level of complex interactions to the learning picture, the addition of the word design to learning is an indicator of this. Daziel et al. explain the widespread use of the phrase "learning design" among practitioners for organizing learning activities, emphasizing that these practitioners actually address designing for learning in planning learning activities (LD-P) rather than taking the other aspects of decision-making into consideration. Daziel et al. point out that considerations for learning design comprise theoretical frameworks as well (LD-F); their contribution in furthering the relationship between the theoretical framework and the practice of organizing is outlined in the Learning Design Conceptual Map (LD$\mathrm{CM})$. They argue that it is possible to construct a notation system that supports the educator in making theoretical as well as practical decisions.

Together with the suggested perspective in Mor et al. (2015), where the conceptual approaches of learning design and instructional design both offer overlaps and gaps in the literature and have a tendency for "siloing" as a consequence, the Danish approach, drawing on a continental concept of didactics, may be perceived to add another aspect of siloing that could be an obstacle for discussing shared challenges, because the challenges are addressed in different languages, e.g. "learning design" versus "didactic design." However, diverse vocabularies and terminologies rooted in different scientific traditions seem to be occupied with the same theoretical issues regarding planning and practicing education. The turning and shared point among the diverse suggestions "learning," "instructional," "educational," "didactic, etc., is their conceptual connection to design. From my point of view, the concept of design indicates a development where continental currents of didactics and Anglo-Saxon currents share issues connected to the theoretical as well as the operational part of education, which leads to a new set of challenges. Design indicates a paradigmatic shift in the role of the educator's conditions for reflecting on, choosing, and planning learning activities. The educator may have to involve other actors in her organizing processes; she will have to think of how learning processes can be facilitated without her actual presence as a teacher, and she may have to negotiate the succession of learning objectives with the learners; she may also have to plan learning activities for learners with whom she will never meet. In addition, she will have to decide how to induct students with diverse educational backgrounds into new scientific domains or professions

While the concept of design comprises the meaning of working with a conceptual map, theoretical framework, and practice, it could also be said that the connection of design to either "learning" or "instructional" leaves out the http://www.lom.dk 
general educational and socialization aspect as expressed in the continental idea of "Bildung" [formation].This implies that critical thinking becomes a skill (exemplified by an instrumental interpretation of 21st-century skills; c.f. quote from the EU report above), and Daziel et al.'s (2013) proposed Learning Design Conceptual Map does not discuss that. General educational and socialization aspects are implied as a foundational premise for considerations in didactic design emphasizing the outlined themes, e.g., critical thinking, problem solving, and creativity connected to $21^{\text {st-century skills. }}$

However, the proposal of the Conceptual Map may help highlight some of these issues as we reflect on the relationship between the theoretical framework for and the design of learning activities. The proposal suggests a common goal of reframing ideas about how educators act and under which conditions. Here may be a common theoretical platform for different theoretical traditions of "learning," "instructional," and "didactical" that may provide fruitful developments by elaborating on the theoretical framework and the conditions for making learning/didactic design decisions. My contribution to elaborating on the relationship between a theoretical framework and the design of learning activities is the introduction of TGP, which prescribes a way of planning learning activities (LD-P) - take the "doing for gaining experience" as a starting point - and is based on a theoretical framework (LD-F). By that, I wish to bring the development rooted in didactics together with current developments in Learning Design. This will be further elaborated on in the next paragraph.

\section{Theoretical framework for theory-generating practices (TGP)}

The starting point for suggesting TGP in education derived from my theoretical and practical background and was formed by didactic insights from the domain-specific subjects I have taught and studied. The manner in which I advocate for a practical outset for theoretical discussions of learning designs has its origin in my 25 years of scientific experience as well as my practical approach to teaching. My background as a visual arts teacher, teacher trainer, and university teacher across the entire educational system (from 1st grade to the highest level of university) has emphasized the educational aspects of pictorial production, in which practical experience from pictorial production played an important part in the learners' learning process, and has also informed my approach when entering the field of ICT and learning 15 years ago. Danish art pedagogy developed in the German Bildung tradition and draws on the German educational philosopher of didactics Klafki's conceptual approach to education as a dialectic process between learning content and learning processes, promoting categorial formation and critical thinking as an educational goal $(1998,2001)$. In this pedagogy (Pedersen, 2004), pictorial production consisted of represented 
more than developing technical skills for art expression or copying canonized art pieces. Instead, art education was assumed to be a constructive process of knowledge generation through the activity and also a reflection of the pictorial production. The subjects for pictorial production were chosen in a broad but learner-centric, relevant field which comprised methods and content from the domain of art as well as the visual cultures of everyday life. The methodology of the teaching subject drew on theoretical insights from both constructivism and activity theory. The approach addressed a classic issue in educational research that has been discussed by scholars investigating the relationship between experience and knowledge generation, as presented by Kolb (1984) and the scholars to whom he referred (e.g., Dewey, Piaget, Bruner, and Freire). Kolb (1984) suggested the discussion revolves around whether learning can be defined as an object, an outcome, or a process. Based on an examination of the work of these scholars, he argued that learning is a process of transforming experience to knowledge and emphasized the importance of taking different epistemological assumptions of different domains into consideration when facilitating a learning process.

Until the reform took effect in 2014, the learning objectives for art education in Danish compulsory school and teacher education centered around the assumption that knowledge emerges from the actual pictorial production process, followed by the learners' reflections, which improve by reflections based on their existing theoretical knowledge and promotes new knowledge. I argued that it is neither production nor reflection that generates new subject knowledge. Instead, it is the relationship between them that produces new subject knowledge - aesthetic as well as representational (Buhl 2003). Furthermore, I argued that the subject knowledge should be chosen and the learning process designed to enhance meaningful activities that promote reflexivity and critical thinking. By emphasizing these aspects of the learning process, the learners could begin to formulate criteria for knowledge building (Buhl, 2004). The focus on the actual practice of generating learning by "doing" constitutes a very literal interpretation of Dewey's (1979) concept of "learning by doing," which can be differentiated from his framework and also furthers it to a very concrete articulation, scaffolded by the teacher's professional guidance. Thus, I took the concept of experience one step further by orchestrating the design for the student's learning processes with a dramaturgy that promoted pictorial production processes of images followed by theoretical reflections supporting the relationship between them. My investigation of this approach proved its potential when engaging with professionalization of student teachers working with and adapting digital technology in visual arts and transforming these processes into didactic knowledge (Buhl, 2002).

The obvious question to ask about my suggested emphasis on experience that is intended to turn the dramaturgy of university teaching upside down is this: What is to be gained? The short answer to this question is to advance the http://www.lom.dk 
practices and enhance the experience from "doing" to promote reflection and to attribute the theoretical activities of reading and discussion with meaning as a result of the direct connection to an emerging problem. The assumption is that experience from doing frames the learning process in a way that enhances the process of problem solving and, far more importantly, the ability of problem setting. In the performing arts domain, including visual arts, music, dance, and singing, teaching practices emerge from supporting the student's ability to master the art form. For the student as well as the teacher, this is a highly skilled, material, and embodied practice, which progresses through a dialectic process between the student and the material (Buhl et al., 2014). Though it may appear to be a linear and straightforward process, this is not the case. Creative processes are never systematic and logical processes. They are a complex of experimenting, visualizing, trial and error, and refinements. They involve experiencing as well as reflections to enhance the processes of knowledge and produce an improved result. From a learning perspective, the processes of learning that involve problem setting as well as problem solving are also connected in this manner. I discuss this idea by suggesting TGP (Buhl, 2013).

My theoretical elaboration on TGP draws on the Hungarian natural and social scientist Polyani's (1966) theoretical concept of tacit knowing: "We know more than we can tell," meaning that knowledge is incorporated in the body. He explained it via the paired concepts of the tacit relationship: the near ("proximal"), which we cannot tell, and the distant ("distal"), which is explicatable. Polyani (1966) argued that science, which does not take the proximal term into account, is unable to work scientifically. Instead, the capability to set a scientific problem is rooted in the knowledge of something hidden or unsolved that needs to be discovered. I suggest that Polyani's (1966) argument explain the difficulties students face in gaining knowledge from theoretical lectures. They are incapable of relating theoretical concepts to the proximal term, which is tacit.

Nonaka (2008) further elaborated on the concept of tacit knowing, suggesting different ways of profiting from it. Appreciating Polyani's (1966) notion of tacit knowing, Nonaka (2008) discussed how the tacit can be productive for both creative and innovative thinking. He worked with four conceptual suggestions for conversion between the tacit and the explicit. They are all important and can be applied to learning activities, but I will focus on only two of them: the conversion of tacit knowledge to explicit knowledge and the conversion of explicit knowledge to tacit knowledge, which are, in agreement with Nonaka (2008), where powerful development happens. This process is also one of the challenges for educators of future scholars. Nonaka (2008) proposed that the conversion of actions can be executed by one person who functions as a mediator for a representative of one sort of knowledge to the representative for another. I suggest that the converting actions can be performed by one and the same person. I further suggest that this converting http://www.lom.dk 
operation constitutes the core of one's ability to generate theoretical knowledge and perform problem setting as well as solving. I am not advocating for a translation process; rather, I argue for the interaction of two equivalent positions that promote knowledge and advocate that the value of the tacit should receive more attention.

The question is how to facilitate the interactional process. I propose a TGP approach to conceptualize and design learning processes. I argue recommend that a learning outset in practical experience promotes the linkage for generating theoretical knowledge of a subject because the articulated experience makes the learning objective concrete. For instance, in performing arts education, the learning is processed in articulations like music, dance, or artistic works or concepts; the articulation per se is knowledge generating, but much of the knowledge is tacit. My hypothesis is that this goes for other knowledge domains as well. This is supported by Nonaka and Takeuchi (1995) and Nonaka (2008), who further claimed that tacit knowledge has two dimensions: the mastery of skills emerging from repetitive actions and the cognitive mental models and schemata reflecting our image of reality ("what is") and the vision of the future ("what ought to be") (Nonaka, 2008). These dimensions of tacit knowledge potentially constitute creative and critical thinking. The tacit is a perceptual and unarticulated skill as well as a cognitive process that can be facilitated in learning activities. Thus, I argue that an increased focus on tacit knowing by interacting with explicit knowing promotes the acquisition of knowledge from being able to act and comprehend. TGP aims to support and strengthen the relationship between practical experiences and generating both tacit and explicit knowledge. This implies that practical experiences precede theoretical reflections.

Furthermore, it implies that a learning session or course dramaturgy should facilitate students' ability to combine practical experiences with the readings and literature of the course taken.

TGPs come in different forms and scales. The turning point is the succession. Every experience may not be explicated in words, but students are given the opportunity to relate their problem setting, problem solving, and theoretical studies to concrete activities of experiencing.

\section{Three examples of practicing TGP as the conceptual principle in learning designs}

The analogy of the outlined approach to visual arts education has proven to be useful in discussing learning design and ICT in a contemporary perspective with regard to focusing on hands-on activities, both in the smallest sense of involving technology in learning activities and also in a broader sense. The TGP experience can easily stem from the involvement of technology, but a process must be lived out and followed by reflective activities. My 
exemplifying case descriptions will show this on a small, medium, and large scale.

The three case descriptions derive from my own teaching and research practice from 2010 to 2014 . TGP was used on a small scale as students planned and conducted a video-observed investigation of their own counseling practice. TGP was used on a medium scale as students were introduced to a Design-Based Research (DBR) approach on their first course day by rapidly working through an iterative process. Finally, in working with a case to produce an IT learning design to solve a problem for an external stakeholder, we integrated TGP on a large scale. Students were asked to begin their final project on the first course day and refine it through iterative processes supported by theoretical studies for the rest of the course. This third case suggests a model that turns the conventional dramaturgy of a course upside down. The re-structuring and re-organization of the courses make the students' operational work with theory more concrete and facilitate a different approach to theoretical reading and discussion.

Subject knowledge informed the approach to concretizing TGP. The three examples I give came from courses I taught in other subjects: a Practices of Guidance course in a master program in Guidance: a Designing Communication: Learning, Network and Organization course in a bachelor program of Communication and Digital Media; and a Visual Cultures and Aesthetics in Digital Communication and Learning Designs course in the Nordic Visual Studies and Art education (NoVA) program. Technology played different roles in the three examples, functioning both as a tool for student learning and design processes and as an integrated part of the learning content and learning practices. While the first two examples were organized as contact teaching that took place on the university campus, the third example was mainly an online course with students from three different universities in three different countries but with an introductory seminar at the hosting university campus. The scaling of examples serves to demonstrate that TGP may be used for minor components parts in the overall learning design of a course as well as being the main principle for a course structure or even a program.

\section{Small-scale example from the master program in Guidance}

The small-scale example derived from the master program in Guidance (2010-2011) aimed at designing a learning process where students turned their own practical experiences as professional counselors of students in vocational or high school programs into objects for analysis. Students in the master program were already working professionally with guidance, but they were also working toward an academic degree in counseling. In the Practice of Guidance course, they were encouraged to create an analytical distance from their own actions in a guidance situation. The means for this involved the production of video observations of themselves "in action" at work while 
having conversations with clients. One challenge was to overcome the strangeness of watching oneself on video and instead turn the video into an object for analysis.

As teachers and researchers, we conducted the course and studied to what extent the video recordings made by the students enhanced an analytical approach to their own guidance practice (Nordentoft \& Buhl, 2012). The part I conducted was designed to draw on TGP. The students were introduced to video recording by being handed a video camera in their first session at the university and then being asked to immediately record each other in a hypothetical guidance situation; simple technical instructions and supervision while practicing the activity followed. The next step was to make video recordings of their own guidance practice and then discuss them in their study group. The third step was a group session with the teacher (me), where the videos were analyzed and discussed. This session was also recorded and served as data for the analysis of video as a means for collective counseling. The overall analysis revealed that video observations and analysis have the potential to create dialectic relationships between normative discourses/models and situated embodied experiences (Nordentoft \& Buhl, 2012).

The learning design facilitated a learning situation where the counselor (master student) received information by being present both as a counselor and as an investigator with a running video camera, but he/she also received information by watching the video-captured version afterwards. I argued that this situation creates a dual space of experience, where both the experience of being a participating actor in the creation process of the empirical data and the experience of being confronted with a videotape of the same process form the rationale for the analysis of the video (Buhl, 2013). I further argued that this dual space takes tacit knowledge into account, which refers to Polanyi's (1966) assumption that knowledge emerges from sensory and conceptual information. Tacit knowledge is recalled in various modes when video is involved: seeing one's own facial expressions, hearing the tone of one's voice, and discovering the bodily placement. These modes are met from the outside when one is confronted with a particular situation once again. The dual space of experience comprises a methodology that bridges bodily presence and analytical distance to empirical data or, in other words, to a TGP. The empirical project suggested that the learners gain knowledge in the intersection between doing, experiencing, and reflecting on the basis of tacit knowledge. TGP takes the bodily experience of being present in one's own counseling situation into account. Bringing video into this process added one more aspect of reflection, because bodily experiences from the situation were reactivated when the students watched themselves on video. Furthermore, the repetition of seeing oneself on video gradually reveals an attention to issues evolving in the situation instead of a focus on one's counseling performance (Buhl, 2013). 
As stated in the project results, TGP with video requires that the university teacher create a learning design that supports the student's process - from planning the video-recorded counseling session, to selecting and analyzing the video, and finally to conducting theoretical discussions of the material. The teacher must support the process of the students to be observant of their own reactions to actions in the situation and to the framing of the situation as such. Furthermore, the teacher must support the students to recognize attribute these experiences' importance as academic experiences because they form an important part of the basis for achieving theoretical knowledge (Buhl, 2013). This process was partly achieved by the students' planning the counseling situation on the basis of theoretical knowledge of the field and partly by conducting sessions in which students could reflect on the processes, where the videos were conceptualized and discussed in theoretical terms with other master students and where the university teacher functioned as a supervisor.

\section{Medium-scale example from the bachelor program in Communication and Digital Media}

The next example derived from a six-hour learning session designed to facilitate bachelor students' adaption to practicing a different methodology than they are accustomed to. The example stems from a program in Communication and Digital Media (2012). The $5^{\text {th }}$ semester course Designing Communication: Learning, Network, and Organization taught students to design, test, and theorize from a design-based research (DBR) approach. It was the first time they were introduced to an approach involving methods that differed from hermeneutics and that also involved the pragmatism of developing an actual IT learning design in collaboration with external stakeholders. The implication was not only a matter of a new learning objective but also a situation involving students who needed to restructure their usual learning pattern and approach to taking a course. From day one, they had to engage proactively in fieldwork and the design of activities along with theoretical studies. Their usual mental model of a course flow had to be reframed. Even though the new approach was introduced and discussed, they found it difficult to take it in, which created uncertainty about what was actually expected from them. The students went through a one-day rapiddesign process in order to counter their uncertainty. They used group work to practice a DBR cycle of field analysis, designing, testing, and reflecting in a sixhour assignment. At the end of the day, they were given the cases they would be working with for the rest of the five-week course in a similar DBR cycle. The first-day experience functioned as a method to recapture the phases in the DBR cycle.

I practiced the TGP learning design here for the first time in 2012, and it has been a part of the course ever since. At the end of the first course, four student groups were interviewed. The interview was based on props (case, technology, charts, and pictures of designs) from the first day and took its 
point of departure in the students' narratives and reflections related to these props. The purpose of the interview was to identify the degree to which TGP promoted a restructuring of the students' approach to taking a course and how the rapid design process supported their work throughout the rest of the course.

The interviews indicated a positive response to TGP: the students showed an immediate response to the props and used them to recall the learning process as such and as a recapturing of the practice and its conceptual framework on the first day. In explaining the methodological shift, they had initially found so difficult, some also reflected on the confusion they experienced in practicing the rapid design. However, they stated that the experience made sense later on in the course when they encountered difficulties conducting a DBR process where they had great responsibility toward the external stakeholders and had to depend on collaboration in their group.

The sample of student groups was based on volunteers. The sample represented $25 \%$ of the enrolled students and was not representative of the total group. Still, it contributed with information regarding how the students connected with material resources, embodied experience, and reflected using a retroactive perspective. The visual detection and sense making of the props were obvious, and the recognition was followed by smiles and laughs and little stories, indicating an expression of tacit knowing through analogies (Nonaka, 2008). All groups were capable of combining the props with recollections of experiences and connecting them to the DBR approach.

\section{Large-scale example from the Nordic Visual Studies and Art Education (NoVA) program}

The large-scale example derived from a master program in Nordic Visual Studies and Art Education (NoVA), a collaboration launched in fall 2014 between Konstfack, Stockholm, Oslo and Akershus University College for Applied Sciences, Aalto University, and Aalborg University. The program explores the possibilities of developing the domain of art education, in which discipline-informed activities are traditionally associated with painting, drawing, or sculpting and have a strong but separate relationship to theoretical developments in the field of art history. In contrast, the NoVA program draws on contemporary currents emerging from the concept of visual culture which suggest that the visual is culturally determined and that visuality must be comprehended in a broad field of perception and social practices. While enrolled in the Visual Culture and Aesthetics in Digital Communication and Learning Design (VCAD) course, the students designed a visual and aesthetic event to promote an augmented reality experience for an audience in the urban space of one of the participating capitols. VCAD involved a combination of face-to-face teaching with location-based and mobile activities involving i-nigma, Instagram, and Pinterest, which comprised their learning materials and platforms. Furthermore, the course included online http://www.lom.dk 
activities via the learning management system Moodle and the presentation and video conferencing system Adobe Connect.

The learning design for the course design was based on TGP and combined the medium-scale rapid-design-process based on a case (see above) with the overall structure of the course, drawing on the same DBR cycle. Thus, the first day's rapid-design process was also the first iteration of what would become the final design that constituted their exam project. The course design can be easily described in just a few words: students produced their final project on the first course day and spent the rest of the course improving it. This largescale example is the most radical demonstration of TGP turning the traditional course structure upside down.

The course evaluation (Buhl \& Ejsing-Duun, 2015) revealed that all of the groups managed to develop, test, and implement a design for a visual event following the outlined course structure. The students' group reports indicated a focus on how to work with these design aspects in relation to ideas for visual culture and the augmented reality experience, as well as reflections on the implementation of the final design. The students' oral and written evaluations revealed domain-specific challenges with regard to the practice of TGP. All students expressed challenges with reflecting theoretically on the basis of practical, hands-on experiences as an academic discipline, but the designs and reports indicate that they actually did practice TGP The students managed to connect practical experience to theoretical reflections, but they had difficulties relating these discussions to the course literature. This difficulty may have resulted from any number of challenges: the literature may have been too hard to read, or the connection to reflections too hard to make; students may not have read the literature as instructed, or they may have postponed reading it until the final report; or students may have been challenged by their expectations toward what university teaching is. The reason cannot be concluded from the data available.

The large-scale example was executed in a subject domain in which the conducting practical experience prior to reflection is well known. In this domain, the explicitness of the tacit learning content is performed through artistic articulations and symbolic utterances. The new aspect in this case was that the entire course design drew on TGP. Students were encouraged to develop knowledge by drawing upon their practical experience and to combine tacit knowing with explicit knowledge instead of keeping them separate (Nonaka). The students evaluated these challenges differently; some took positive positions, while others took more reserved positions (Buhl \& Ejsing-Duun, 2015).

The three examples show different educational practices of TGP. In presenting the three examples, I wish to demonstrate that TGP is possible to apply as a principle for learning design on different scales and in different domain- 
specific subjects. Further empirical studies could reveal how TGP works in various subject domains where practicing and theorizing based on experiencing have different roles.

\section{New paths to follow for learning design}

I started by asking this question: How do we develop teaching practices in higher education in light of digital technology?

My exploration of the potential of TGP is motivated by a wish to contribute to the ongoing endeavors to develop university pedagogy in light of the developments in technology - developments that offer new possibilities for learning design. As demonstrated in the three examples, the development of TGP-based learning designs reveals that there is room in education for handson experience prior to reflection. TGP has the potential to enhance students' academic competences by providing them with tools for working with theoretical issues. More important, TGP places the students as the main actors in the learning process, which is crucial for developing $21^{\text {st-century }}$ skills. TGP proposes a path beyond the traditional skills. It promotes competences like problem setting and problem solving, and it facilitates creative and critical thinking. The concretization of "doing" and "living through" provides experience, which would not occur via pure theoretical exercises. By activating tacit knowledge in actual actions, issues appear and promote reflections that could not have been predicted by the students. Emerging digitalization has exposed the need to develop new settings for engaging students in learning activities where all sorts of knowledge can be utilized, because contemporary issues require skills to actually identify and act on them.

The art field has a tradition from artistic production for practicing and experimenting with different answers, drawing on experience that is embodied but not explicit in order to seek new paths, pose new questions, and articulate new actions. The field of art education in Denmark has a tradition of combining this practical experience with reflection; art teachers have long connected experience to theoretical studies of subject-related issues as well as pedagogical issues. I suggest that this interdependency between practicing and reflecting has perspectives to offer learning design - perspectives from which other subject domains can profit.

To make that happen, teacher competences must go beyond designing for learning in the planning and practice of learning activities. The educator must professionalize her pedagogical models and base her didactic decisions on a theoretical framework that enhances her educational and pedagogical goals for student learning activities. This implies that she must create an analytical distance from her own work as well. To get there, she has to determine the relationship between her tacit knowing about her own teaching practices and 
the explicit knowledge derived from frameworks and concepts. Most tacit experiences with learning designs derive from images and metaphors experienced from being a student oneself, as well as from mutual expectations of how university teaching takes place. As Schön (1983) points out, the reflective practitioners' knowledge is based on practice (and this is a good place to start!). Every time a learning design has been practiced, the teacher has achieved experience of both a tacit and explicit nature, which has the potential for didactic reflection and theoretical thinking (Dale, 1989). All three examples showed not only empirical evidence of students learning from their own experienced theory-generating practice; the educator (me) learned from the experience of designing it for them as well. Thus, my suggested principle has potential, not only for developing students' learning processes but also as an analytical tool to develop the university teachers' teaching practice. By reflecting on teaching as a practice that is embodied and tacit, one may develop the ability to imagine different ways of "doing".

The dramaturgy of lecture-hall instruction leading up to a final test is an internalized knowing as well asan institutionalized university practice. Even many project- and problem-based learning concepts follow the linear dramaturgy of explicit knowledge building up to a final project. It will take time to make a change where another practice can be internalized and become a tacit component of university pedagogy. This turning of course dramaturgy upside down does not alone "do the trick." It may, however, start a conversation about how to stimulate and facilitate learning activities that acknowledge the potential of "doing" - experiencing from actual practices - as a way of promoting problem setting and solving, generating new knowledge, and developing criteria for using that knowledge. 


\section{References}

Andreasen, L. B., Meyer, B., \& Ratleff, P. (2008). Digitale medier og didaktisk design. København: Aarhus Universitetsforlag.

Buhl, M. (1999). Det levende billede-den levende krop. København: Danmarks Lærerhøjskole, Center for Billedpædagogisk forskning. Billedpædagogiske studier. Bd 4.

Buhl, M. (2002). Paradoksal billedpædagogik. København: Danmarks Pædagogiske Universitets Forlag.

Buhl, M. (2003). Praktik starter på seminaret. In author, K. Meisner Christensen, \& K. Skov. Praktik set i lyset af billedkunstfaget. København: Zahles Seminarium, Kamelrefleksioner bd.

Buhl, M. (2004). Visual culture as a strategic approach to reflection. Nordic educational studies, 4

Buhl, M. (2013). Video as a means for academic improvement of a profession. A discussion of theory-generating practice. In A. Kraus \& A. Herbert (eds.). Praxeology as a Challenge: Modeling the Tacit Dimensions of Pedagogy (s. 109-125). European Studies on Educational Practices, 3. Münster: Waxmann Verlag.

Buhl, M., Ørengreen, R. \& Levinsen, K. (2014). Teacher performance in the performing arts. In A. Kraus, author, \& B. von Carlsburg (eds.), Performativity, materiality and time. European Studies on Educational Practices, 3. Münster: Waxmann Verlag.

Buhl, M. \& Ejsing-Duun, S. (2015). Blended learning promoting new developments for Nordic master programs in visual studies and art education. In A. Jeffries \& M. Curbric (eds.), Proceedings of the 14th European Conference on e-Learning ECEL (s. 100-107). Academic Conferences and Publishing International Limited.

Conole, G. (2013). Designing for learning in an open world. New York: Springer.

Dale, L. E. (1989). Pedagogisk profesjonalitet. Oslo: Gyldendal.

Daziel, (2015). Reflections on the art and science of learning design and the Larnaca Declaration. In M. Maina, B. Craft, \& Y. Mor (eds.), The art and science of learning design. Rotterdam//Boston/Tapei: Sense Publishers.

Daziel, J., Conole, G., Wills, S., Walker, S., Bennet, S., Dobozy, E. ... Bower, M. (2013). The Larnaca Declaration on learning design-2013. Retrieved from www.larnacadeclaration.org

Dewey, J. (1979/1938). Experience and education. New York: Collier Books.

Dobozy, E. (2011). Typologies of learning design and the introduction of a "LD-Type 2" case example. eLearning Papers, 27 s. 1-11. 
European Commision Directorate-General for Education and Culture. (2008). Education and training 2010 work programme. Cluster key competences - curriculum reform synthesis report on peer learning activities 2007. Retrieved from http://ec.europa.eu/education/policy/school/doc/peer07_en.pdf

Habermas, J. (1996). Teorien om den kommunikative handlen. Aalborg: Aalborg Universitetsforlag.

Hiim, H., \& Hippe, E. (1997). Læring gennem oplevelse, forståelse og handling: en studiehåndbog i didaktik. København: Gyldendal undervsining.

Holm Sørensen, B., Audon, L., \& Levinsen, K. (2010). Skole 2.0. Aarhus: Klim.

Hopmann, S., \& Gundem, B. B. (1998). Didaktik and/or curriculum. New York: Peter Lang Publishing.

Jank, W., \& Meyer, H. (1991). Didaktische Modelle. Frankfurt a. M: Cornelson Scriptor.

Kolb, D. A. (1984/2006). Experiential learning: Experience as the source of learning and development. Englewood Cliffs, NJ: Prentice-Hall.

Klafki, W. (2001/1985). Dannelsesteori og didaktik. Nye studier [Org.: Neue Studien zur Bildungstheorie und Didaktik], Klim, Aarhus.

Klafki, W. (1998). Den kategoriale dannelse, I Dale, E.L (red.). Undervisning og barnets udvikling. Klassiske tekster. Oslo: Gyledendal

Lave, J., \& Wenger, E. (1991). Situated learning. Legitimate peripheral participation. New York: Cambridge University Press.

Larsen, C. A., \& Høgh-Larsen, C. A (1997). Didaktiske emner belyst gennem 12 artikler. Erik Jensen. (ed.). København: Danmarks Pædagogiske Bibliotek

Luhmann, N. (2000). Sociale systemer. København: Hans Reitzels Forlag.

Luhmann, N. (2002). Das Erziehungssystem der Gesellschaft. Frankfurt am Main: Suhrkamp Taschenbuch Verlag.

McAuley, A., Stewart, B., Siemens, G., \& Cormier, D. (2010). The MOOC Model for Digital Practice, elearnspace. Retrieved from http://www.elearnspace.org/Articles/MO0C_Final.pdf

Meyer, B. (ed.). (2011). It-didaktisk Design. Cursiv 11.

Mor, Y., Craft, B., \& Maina, M. (2015). Introduction: Learning design:

Definitions, current issues and grand challenges. In M. Maina, B. Craft, \& Y. Mor (eds.). The art and science of learning design.

Rotterdam//Boston/Tapei: Sense Publishers.

Nielsen, F. V. (1998). Almen Musikdidaktik. København: Akademisk Forlag. 
Nonaka, I. (2008). The knowledge creating company. Boston: Harvard Business Press.

Nonaka, I., \& Takeuchi, H. (1995). The knowledge creating company. How Japanese companies create the dynamics of innovation. Oxford: Oxford University Press.

Nordentoft, M., \& author. (2012). Multimodality and video observation in "Collective academic supervision" in the master programme in Guidance Aarhus University. In R. Ørngreen (ed.), Denmark, Designs for learning 2012, 3rd international conference exploring learning environments (pp.120-122). 25-27 April 2012, Copenhagen, Denmark.

Polyani, M. (1966/1983). The tacit dimension. Glouchester: Peter Smith.

Pedersen, K. (2004). Rekonstruktion af billedpædagogikken. København: Danmarks Pædagogiske Universitetsforlag

Schnack, K. (ed.) (2004). Didaktik på kryds og tværs. Aarhus: Aarhus Universitetsforlag.

Schön, D. A. (1983/2001). The reflective practitioner. How professionals think in action. London: Temple Smith

Siemens, G. (2005). Connectivism: A learning theory for a digital age. elearnspace. Retrieved from http://www.elearnspace.org/Articles/connectivism.htm

Vygotsky, L.S. (1986). Thought and Language Cambridge, MA: MIT Press 